CIVICS EDUCATION AND SOCIAL SCIENSE JOURNAL(CESSJ)

Volume 2 Nomor 2 Edisi Bulan Desember 2020

\title{
PEMBELAJARAN VIRTUAL PADA MASA PANDEMIC COVID-19: TANTANGAN DAN SOLUSI PERMASALAHAN
}

\author{
Penulis \\ Sopyan Sauri ${ }^{1}$, Tatu Munawaroh ${ }^{2}$, Dody Riswanto ${ }^{3}$, Siti Nurbani ${ }^{4}$ \\ Universitas Mathla'ul Anwar Banten \\ email: sopyannsaurii@gmail.com
}

\begin{abstract}
ABSTRAK
Tujuan penelitian ini adalah melihat fenomena pembelajaran virtual pada masa pandemic Covid-19 beserta tantangan dan solusi permasalahan yang harus dilakukan.Penelitian ini bertujuan untuk melihat sejauh mana kesiapan institusi pendidikan, guru, dosen, siswa, maupun mahasiswa melaksanakan peralihan atau masa transisi dari pembelajaran konvensional menuju pembelajaran berbasis virtual.Jenis penelitian yaitu pendekatan kualitatif.Obyek penelitian adalah fenomena pembelajaran virtual di institusi pendidikan, sedangkan subyek penelitian adalah peserta didik/mahasiswa.Metode pengumpulan data yang dilakukan adalah observasi, studi dokumentasi, dan informasi audio visual.Analisis data yang digunakan yaitu mengorganisasikan data, memilah data yang primer dengan teknik triangulasi data, mensintesiskan data, menemukan pola, dan interpretasi data untuk selanjutnya dilakukan langkah akhir yaitu menemukan makna sebagai tujuan akhir analisis kualitatif. Hasil penelitian terdiri dari (1) kesiapan guru dan dosen mengoperasikan perangkat teknologi informasi, (2) Jaringan internet yang stabil pada beberapa wilayah di Indonesia (3) Insentif biaya bagi peserta didik untuk membeli kuota internet (4) metode pembelajaran guru atau dosen yang inovatif (5) tidak memberi beban pekerjaan rumah secara berlebihan kepada siswa.
\end{abstract}

Kata Kunci: Pembelajaran, Virtual, Pandemic Covid-19, Tantangan, Solusi Permasalahan. 


\title{
VIRTUAL LEARNING DURING COVID PANDEMIC -19: CHALLENGES AND SOLUTIONS TO PROBLEMS
}

\author{
Aouthors \\ Sopyan Sauri ${ }^{1}$, Tatu Munawaroh ${ }^{2}$, Dody Riswanto ${ }^{3}$, Siti Nurbani ${ }^{4}$ \\ Universitas Mathla'ul Anwar Banten \\ email: sopyannsaurii@gmail.com
}

\begin{abstract}
The purpose of this study is to look at the virtual learning phenomenon during the Covid-19 pandemic along with the challenges and problem solutions that must be done. This study aims to see the extent to which educational institutions, teachers, lecturers, students and students are prepared to carry out the transition or transition from conventional learning to virtual-based learning. This type of research is a qualitative approach. The research object is the virtual learning phenomenon in educational institutions, while the research subjects are students. The data collection methods used were observation, documentation study, and audio-visual information. The data analysis used was organizing the data, sorting primary data with data triangulation techniques, synthesizing data, finding patterns, and interpreting the data, then the final step was to find meaning as the ultimate goal of qualitative analysis. The results of the study consisted of (1) the readiness of teachers and lecturers to operate information technology devices, (2) a stable internet network in several regions in Indonesia (3) Cost incentives for students to buy internet quotas (4) innovative teacher or lecturer learning methods (5) not overloading students with homework.
\end{abstract}

Keywords: Learning, Virtual, Pandemic Covid-19, Challenges, Problem Solutions. 


\section{PENDAHULUAN}

Corona virus disease dengan kode virus Sars-CoV-2 adalah pandemic yang muncul pertama kali di Tiongkok pada akhir tahun 2019. Covid-19 yang menyebar ke seluruh dunia pada awal tahun 2020 telah membawa dampak perubahan besar bagi kehidupan manusia, dampak perubahan pada semua sektor yaitu bidang ekonomi, kesehatan, politik, sosial, pendidikan, kemiskinan, pengangguran, teknologi informasi, dan lain-lain.

Pemulihan pasca Covid-19 diatur oleh pemerintah berdasarkan rekomendasi WHO, yaitu harus memperhatikan protokol kesehatan, yaitu memakai masker ketika di luar ruangan, cuci tangan memakai sabun antiseptik, physical distancing, hal ini diatur agar perekonomian suatu negara tidak mengalami collaps akibat pandemic Covid-19, maka pemulihan pasca Covid-19 diatur oleh pemerintah melalui kebijakan dan peraturan.

Pemulihan pasca Covid-19 yang didefinisikan sebagai new normal diatur oleh pemerintah, dan berdampak pada berbagai sektor diantaranya adalah bidang pendidikan.Menteri pendidikan membuat aturan yaitu meliburkan sekolah selama pandemic Covid-19 dan meniadakan ujian nasional bagi siswa kelas akhir, kebijakan ini terus berlanjut sampai memasuki tahap transisi new normal.

Kebijakan menteri pendidikan meliburkan sekolah selama pandemic Covid-19 telah melahirkan reformasi baru yaitu pembelajaran secara online atau virtual.Pembelajaran virtual adalah pembelajaran jarak jauh memanfaatkan layanan internet, menggunakan aplikasi seperti video teleconference, audio visual, dan lain-lain. Kebijakan belajar dari rumah menimbulkan kebiasaan dan kebudayaan baru bagi peserta didik, yaitu pembelajaran virtual. Hal ini tentu berdampak pada proses pembelajaran dari metode konvensional ke metode virtual atau berbasis online. Tantangan dan kendala harus dihadapi guru, dosen dan para peserta didik selama proses pembelajaran virtual.

Mengubah kebiasaan lama menjadi kebiasaan baru tentu memerlukan waktu dan proses adaptasi. Guru, dosen, dan peserta didik tentu memerlukan proses adaptasi untuk menyesuaikan proses pembelajaran dari metode konvensional ke metode virtual. Proses adaptasi perubahan pembelajaran ini menuntut kesiapan dari para guru dan dosen dan semua peserta didik di sekolah. Gurumaupun dosentelah terbiasa melaksanakan pembelajaran secara konvensional melalui layanan klasikal di ruang kelas. Perubahan proses pembelajaran dari metode konvensional ke metode virtual tentu berdampak positif dan juga negatif. Sebagian guru dan dosen siap menghadapi perubahan model pembelajaran tersebut, sebagian yang lain merasa tidak siap menghadapi perubahan model pembelajaran berbasis virtual. Bagi guru maupun dosen yang siap menghadapi perubahan tersebut, pembelajaran virtual berdampak positif pada proses layanan pembelajaran, perkembangan teknologi informasi memberikan kemudahan terhadap akses pembelajaran, tapi bagi yang tidak siap, pembelajaran virtual tentu menjadi beban dan masalah disebabkan kebiasaan guru dan dosen selama ini terpusat pada metode pembelajaran konvensional. 
Tantangan dan kendala dihadapi guru dan dosen yang tidak siap merubah kebiasaan belajar menggunakan metode online atau virtual.Diantaranya tingkat kesiapan guru-guru dan dosen berusia tua untuk mengoperasikan perangkat teknologi yang terbatas. Guru maupun dosen yang berusia tua seringkali lambat dalam mengaplikasikan pembelajaran berbasis virtual atau e-learning, guru maupun dosen yang berusia tua seringkali mengandalkan metode pembelajaran konvensional daripada mencoba belajar mengandalkan perangkat teknologi. Di sisi lain, guru dan dosen yang berusia muda lebih siap dan mahir dalam mengoperasikan perangkat teknologi untuk proses pembelajaran, guru dan dosen yang berusia muda seringkali mengikuti perkembangan teknologi informasi dan mencoba berinovasi menggunakan perangkat teknologi untuk menunjang proses pembelajaran.

Bagi sebagian peserta didik, kebijakan libur sekolah dalam jangka waktu lama tentu berdampak pada proses pembelajaran mereka secara keseluruhan. Sebagian peserta didik merasa senang dengan kebijakan libur sekolah yang lama, sebagian lain merasa bosan dan ingin kembali ke sekolah, sebagian lainnya merasa senang proses pembelajaran berubah menjadi metode virtual, sebagian lain merasa terbebani dengan perubahan proses pembelajaran virtual. Tingkat kesiapan peserta didik dalam menghadapi pembelajaran virtual berbeda-beda, sebagian merasa siap, karena ditunjang dengan fasilitas dan sarana yang memadai, sebagian lain tidak siap, disebabkan fasilitas dan sarana yang tidak mendukung, contohnya keterbatasan jaringan internet, kurangnya biaya untuk membeli paket internet, kurangnya perangkat elektronik yang mendukung yaitu laptop atau android.

Di sisi lain, bagi sebagian peserta didik yang memiliki tingkat ekonomi rendah, pembelajaran virtual tentu menjadi tantangan dan kendala disebabkan keterbatasan biaya untuk membeli sarana dan fasilitas perangkat elektronik, bagi murid yang miskin hal ini tentu menjadi beban dan masalah dalam melaksanakan proses pembelajaran virtual. Tantangan dan kendala dihadapi sebagian peserta didik dalam melaksanakan pembelajaran virtual, diantaranya keterbatasan jaringan internet, pekerjaan rumah dari guru atau dosen yang lebih banyak, tingkat kesiapan peserta didik dalam memahami materi pembelajaran, guru ataupun dosen yang memberikan instruksi atau perintah kurang jelas dan kurang dipahami sebagian peserta didik, dan lain-lain.

Jaringan internet yang terbatas menjadi hambatan dan kendala dalam melaksanakan pembelajaran virtual.Hal ini tentu menjadi masalah yang dihadapi para peserta didik.Bagi sebagian peserta didik yang tidak terjangkau jaringan internet, mereka tidak dapat mengakses pembelajaran yang disampaikan oleh guru atau dosen, akibatnya mereka tertinggal dalam memahami materi pembelajaran. Sebagian peserta didik terpaksa harus berjalan keluar rumah untuk menjangkau jaringan internet. Hal ini tentu menjadi masalah disebabkan sebagian wilayah kota menerapkan kebijakan Lockdown atau pembatasan sosial berskala besar (PSBB). Regulasi PSBB mengharuskan setiap orang untuk membatasi kegiatan di luar rumah, jika bukan kegiatan yang bersifat urgent atau sangat penting.

Tantangan yang dihadapi sebagian peserta didik dalam pembelajaran virtual lainnya adalah pekerjaan rumah yang diberikan lebih banyak dari pada 
pekerjaan rumah pada pembelajaran konvensional. Gurumaupun dosen memberikan beban pekerjaan rumah lebih banyak yang membuat murid banyak mengeluh, hal ini menegaskan bahwa para peserta didik tidak siap dengan beban tugas yang lebih banyak. Tantangan lainnya adalah pemahaman para peserta didik terhadap materi yang diberikan melalui pembelajaran visual. Pemahaman peserta didik tentu memiliki tingkat yang berbeda-beda tergantung kemampuan intelegensi yang dimiliki mereka.Pada sebagian guru ataupun dosen yang melaksanakan pembelajaran visual, beberapa murid tidak paham terhadap materi yang dijelaskan meskipun guru dan dosentelah menjelaskan secara berulangulang.

Sebagian peserta didik dalam pembelajaran visual hanya diam dan tidak memberikan respon terhadap materi yang dijelaskan, guru dan dosen tentu kesulitan memberikan evaluasi pembelajaran, apakah mereka paham dan mengerti berkaitan materi yang dijelaskan, atau peserta didik takut merespon dan memberikan jawaban disebabkan guru ataupun dosen akan marah dan memberikan nilai rendah kepada peserta didik. Tantangan terbesar dalam pembelajaran visual adalah metode pengajaran guru atau dosen yang harus dipahami dan dimengerti semua peserta didik. Dalam pembelajaran visual, guru maupun dosen harus memiliki metode pengajaran yang kreatif, inovatif, menyenangkan, sehingga peserta didik mengerti dan paham materi yang dijelaskan, pembelajaran visual bukan alasan bagi guru atau dosen untuk memberikan pekerjaan rumah lebih banyak kepada peserta didik.

Pembelajaran visual tentu menjadi alternatif metode pembelajaran yang digunakan pada saat pandemic Covid-19.Gurudan dosen harus memanfaatkan kesempatan ini untuk mengembangkan mutu pembelajaran disebabkan pemanfaatan teknologi informasi membutuhkan daya kreatifitas yang tinggi. Pemanfaatan teknologi informasi sebagai sarana pembelajaran harus dipelajari dan dipahami oleh semua guru dan dosen, agar dapat memberikan pembelajaran maksimal kepada para peserta didik.

Tujuan penelitian ini adalah melihat fenomena pembelajaran virtual pada masa pandemic Covid-19 beserta tantangan dan solusi permasalahan yang harus dilakukan.Penelitian ini bertujuan untuk melihat sejauh mana kesiapan institusi pendidikan, guru, dosen, siswa, maupun mahasiswa melaksanakan peralihan atau masa transisi dari pembelajaran konvensional menuju pembelajaran berbasis virtual.

\section{KAJIAN TEORI}

Hasil penelitian dilakukan beberapa guru dengan mengembangkan media pembelajaran berbasis android dengan format aplikasi package (apk). Hasil penelitian di Junior High School provinsi Yogyakarta tahun 2017 menghasilkan media pembelajaran mobile learning berbasis android untuk siswa Junior High School (SMP) yang disusun dalam format aplikasi package (apk). Media pembelajaran mobile learning dinilai sangat baik digunakan berdasarkan hasil uji alpha dengan rata-rata skor dari ahli materi sebesar 4,15 dan rata-rata skor dari 
ahli media sebesar 4,1 serta berdasarkan hasil uji beta kelompok kecil memperoleh rata-rata 4,5 hasil uji beta kelompok besar memperoleh rata-rata 4,3, sedangkan persentase kelulusan peserta didik pada saat pelaksanaan pretest $11,7 \%$ dan pada saat pelaksanaan post test sebesar 100\% (Ibrahim and Ishartiwi, 2017).

Hasil pengembangan penelitian di sekolah Daruttaqwa di Kabupaten Gresik, Provinsi Jawa Timur tahun 2016, menyebutkan bahwa pembelajaran Virtual melalui pengembangan aplikasi android, dengan pembuatan perangkat lunak menggunakan metode waterfall terbukti efektif memberikan kemudahan bagi siswa-siswa dan guru-guru sekolah dalam proses belajar dan mengajar online (Susanto et al, 2016). Hasil penelitian di kota Malang tahun 2017 menyebutkan bahwa pembelajaran virtual berbasis android berupa game quiz pada materi barisan dan deret matematika mampu memotivasi siswa dalam berlatih mengerjakan soal matematika, dengan hasil skor validasi media sebesar 3,43 dan validasi materi sebesar 3,57 (Setyadi, 2017).

Berdasarkan penelitian dan pengembangan yang dilakukan beberapa peneliti di beberapa wilayah di Indonesia, terbukti bahwa pembelajaran virtual berbasis pengembangan aplikasi android atau smartphone teruji valid memberikan kemudahan bagi siswa dan guru untuk melaksanakan pembelajaran berbasis online atau virtual. Pembelajaran virtual lainnya yang digunakan guru dan siswa adalah Google Classroom.Classroom adalah rangkaian fitur produktivitas gratis yang mencakup email, dokumen, dan penyimpanan. Classroom dirancang bersama dengan para pengajar untuk membantu mereka menghemat waktu, menjaga agar kelas tetap teratur, dan meningkatkan komunikasi dengan siswa (Support.Google, 2020).

Google Classroom membuat kegiatan belajar mengajar menjadi lebih produktif dan bermakna dengan menyederhanakan tugas, meningkatkan kolaborasi, dan membina komunikasi.Pengajar dapat membuat kelas, memberikan tugas, mengirim masukan, dan melihat semuanya di satu tempat.Classroom juga terintegrasi secara lancar dengan fitur Google lainnya seperti Google Dokumen dan Drive (Support.Google, 2020). Berdasarkan hasil pelatihan kepada guru-guru di kabupaten Rokan Hulu, provinsi Riau tahun 2020, yang dilaksanakan tim dosen Universitas Pasir Pengaraian menyebutkan bahwa pemanfaatan Google Classroomsebagai media pembelajaran virtual berdampak positif bagi guru-guru dalam proses belajar mengajar di Senior High School (Yanto et al, 2020).

Layanan pembelajaran virtual berupa Google Classroom memiliki kemudahan diantaranya materi pembelajaran mudah diakses, siswa terlibat langsung dalam pembelajaran memanfaatkan internet, dan melatih keterampilan literasi data dan literasi teknologi (Nurfalah, 2019). Hasil penelitian di kota Pekanbaru tahun 2020 menyebutkan bahwa penggunaan virtual learning dengan Google Classroom berpengaruh terhadap hasil belajar dan motivasi siswa pada materi sistem pencernaan di kelas XI jurusan eksak pada senior high school (SMA) Nurul Falah Pekanbaru berupa hasil N-Gain kelas eksperimen lebih besar 
dari nilai N-Gain kelas kontrol (Rikizaputra and Sulastri, 2020). Hasil penelitian di Universitas Muslim Maros, Provinsi Sulawesi Selatan tahun 2019, menyebutkan bahwa terdapat pengaruh signifikan media pembelajaran Google Classroom terhadap motivasi belajar mahasiswa Semester V Program Studi Pendidikan Matematika FKIP Universitas Muslim Maros.Hal ini ditunjukkan dengan nilai statistik uji hipotesis yang diperoleh bahwa H0 ditolak. Selain itu, dapat dilihat pula skor nilai rata-rata hasil belajar mahasiswa 78,31yang berada pada kategori tinggi dan nilai persentase respon mahasiswa sebesar 83,72\% (Nirfayanti and Nurbaeti, 2019).

Hasil penelitian di STMIK STIKOM Indonesia di kota Denpasar Bali tahun 2019 menyebutkan bahwa penggunaan Google Classroom efektif untuk mengembangkan kemampuan pemecahan masalah mahasiswa menjadi lebih baik. Disamping itu keefektifan dari penggunaan Google Classroom dapat dilihat dari respon yang positif dari mahasiswa.Hal tersebut dapat disimpulkan dari hasil pekerjaan mahasiswa beserta jawaban mahasiswa dalam kuesioner tertutup yang diberikan secara daring (Maharani and Kartini, 2019). Hasil pengolahan data di Universitas Teuku Umar tahun 2020 menyebutkan bahwa 165 orang mahasiswa Fakultas Ekonomi, lebih nyaman menggunakan aplikasi Google Classroom untuk digunakan dalam model pembelajaran daring. Aplikasi tersebut telah mereka kenal sebelumnya atau mudah dipahami karena cenderung serupa dengan beberapa aplikasi yang biasa mereka gunakan untuk kegiatan sehari hari (Zhafira et al, 2020).

\section{METODE}

Metode yang digunakan dalam kajian penelitian ini menggunakan pendekatan kualitatif.Penelitian kualitatif berpijak pada kekuatan peneliti yang berperan sebagai instrument penelitian dalam mengolah data riset.Penelitian kualitatif adalah suatu pendekatan yang digunakan untuk mengeksplorasi dan memahami makna individu atau suatu kelompok tertentu yang berkaitan dengan masalah sosial (Creswell, 2013).

Teknik pengumpulan data yang digunakan observasi, studi dokumentasi, dan informasi audio visual.Observasi dilaksanakan dengan mengamati pembelajaran virtual di Universitas Mathla'ul Anwar Banten, yang memberlakukan pembelajaran virtual pada masa pandemic Covid-19.Studi dokumentasi didapat dengan mengumpulkan data-data primer menghitung jumlah rata-rata mahasiswa yang menggunakan aplikasi pembelajaran virtual, data mahasiswa yang menggunakan smartphone, dan lain-lain.Informasi audio visual didapat dengan melihat kegiatan mahasiswa selama pembelajaran virtual berlangsung.

Analisis data yang digunakan yaitu mengorganisasikan data, memilah data yang primer dengan teknik triangulasi data, mensintesiskan data, menemukan pola, dan interpretasi data untuk selanjutnya dilakukan langkah akhir yaitu menemukan makna sebagai tujuan akhir analisis kualitatif. 


\section{HASIL PENELITIAN DAN PEMBAHASAN}

Para guru dan dosen tentu memerlukan adaptasi untuk menyesuaikan pembelajaran dari metode konvensional ke metode visual. Proses adaptasi ini akan menentukan berhasilnya guru dalam melaksanakan pembelajaran visual. Proses adaptasi ini tentu harus dilakukan disebabkan perkembangan teknologi informasi terus berkembang, guru dan dosen harus siap untuk mengembangkan layanan dan mutu pembelajaran yang inovatif kepada peserta didik.

Beberapa aplikasi yang digunakan sebagai media pembelajaran virtual diantaranya adalah Zoom, Google Classroom, Google Meet, Skype, Ruang guru, pengembangan aplikasi android atau mobile learning, dan lain-lain. Penggunaan aplikasi dipilih tergantung pada kemudahan akses dari masing-masing aplikasi yang memiliki keunggulan, yaitu pengguna free atau tidak berbayar, pengguna aplikasi berbayar, kelengkapan fitur aplikasi yang memudahkan pembelajaran, dan lain-lain.

Pembelajaran virtual berbasis android atau mobile learning dilakukan dengan cara mengembangkan aplikasi android, untuk menggunakannya, android atau smartphone yang dimiliki siswa harus terkoneksi dengan internet, pengembangan aplikasi android untuk pembelajaran virtual tergantung dari pengembangan masing-masing guru dan dosen, sesuai dengan need assessment hasil penelitian dan tingkat kebutuhan peserta didik. Solusi permasalahan pembelajaran virtual berkaitan dengan kesiapan guru dan dosen untuk mengoperasikan perangkat teknologi informasi.Beberapa guru atau dosen belum siap untuk melakukan perubahan pembelajaran secara virtual disebabkan mereka tidak dapat mengoperasikan perangkat teknologi informasi.Pada akhirnya, pendidik yang tidak siap terhadap perubahan pembelajaran virtual kembali pada metode pembelajaran konvensional, pada masa transisi pandemic Covid-19 tentu pembelajaran konvensional kurang efisien dilaksanakan disebabkan tingkat penularan yang tinggi dan sebagai upaya untuk memutus penularan Covid-19, maka regulasi pemerintah yaitu melaksanakan pembelajaran secara virtual.

Guru dan dosen harus belajar mengoperasikan perangkat teknologi informasi, khususnya guru dan dosen yang telah berusia tua, disebabkan usia mereka tua, proses pembelajaran mengoperasikan perangkat teknologi dirasakan sulit, dibandingkan dengan tenaga pengajar yang berusia muda yang mahir mengoperasikan semua perangkat teknologi informasi, karena itu guru atau dosen yang berusia tua harus menurunkan ego mereka dan mulai belajar untuk mengoperasikan perangkat teknologi informasi untuk pembelajaran. Solusi permasalahan pembelajaran virtual yang berkaitan dengan jaringan internet tidak stabil.Sebagian peserta didik tidak dapat mengakses pembelajaran virtual disebabkan kurangnya jaringan internet yang stabil di beberapa wilayah. Tidak semua wilayah Indonesia, seperti pedesaan, pegunungan, dan pedalaman, memiliki tower jaringan internet yang cukup, pada beberapa wilayah, khususnya daerah yang memiliki infrastruktur kurang layak, penyediaan sarana dan prasarana untuk jaringan internet masih sangat kurang. 
Guru dan dosen harus paham dan mengerti, apabila sebagian peserta didik tidak dapat melaksanakan pembelajaran virtual disebabkan akses jaringan internet yang kurang, tidak memaksakan sepenuhnya pembelajaran secara virtual kepada semua siswa, guru atau dosen harus mencari solusi alternatif permasalahan dengan kreatif dan inovatif. Pembelajaran virtual tetap dilaksanakan pada situasi pandemic Covid-19, namun guru tetap harus bijaksana mencari solusi permasalahan agar semua siswa dapat mengakses pembelajaran secara menyeluruh tanpa kendala jaringan internet. Solusi permasalahan pembelajaran virtual berkaitan dengan insentif biaya bagi peserta didik untuk membeli kuota internet.Pandemic Covid-19 berdampak pada tingkat pengangguran yang tinggi, banyak pekerja dipecat atau disuruh istirahat sementara oleh perusahaan atau institusi, mengakibatkan tidak adanya pendapatan dan gaji yang diterima pekerja, hal ini tentu berdampak pada ekonomi yang memburuk.

Orang tua dari peserta didik terimbas pengangguran tidak mampu membayar biaya sekolah atau biaya kuliah termasuk biaya kuota internet.Hal ini berimbas pada pembiayaan sekolah anak-anak, Pemerintah, anggota dewan, dan institusi pendidikan harus membuat peraturan untuk memberikan keringanan biaya kepada semua siswa, diantaranya biaya untuk membeli kuota internet. Solusi permasalahan pembelajaran virtual berkaitan dengan metode pembelajaran guru dan dosen yang inovatif.Diantara tantangan yang dihadapi tenaga pengajar dalam melaksanakan pembelajaran virtual adalah materi pembelajaran yang diberikan bisa dimengerti dan dipahami oleh semua peserta didik.Tidak semua murid mengerti dan paham terkait materi pembelajaran yang dijelaskan guru atau dosen, disebabkan metode pengajaran yang kurang inovatif dan cenderung membosankan.

Disebabkan metode pembelajaran guru atau dosen yang kurang inovatif, murid menjadi mudah bosan, dan kurang semangat dalam melaksanakan pembelajaran. Gurudan juga dosen harus mengubah metode pembelajaran agar peserta didik menjadi lebih mudah mengerti dan paham. Contoh metode yang bisa diberikan adalah memberikan game atau quiz yang menyenangkan, humor, ice breaking, menonton video yang menarik, mendengarkan musik, memberikan hadiah seperti kuota internet gratis, buku dan lain-lain. Solusi permasalahan pembelajaran virtual berkaitan dengan tidak memberi beban pekerjaan rumah secara berlebihan kepada peserta didik.Diantara permasalahan pembelajaran virtual adalah keluhan murid terhadap beban pekerjaan rumah yang semakin banyak.Murid menghitung dari kalkulasi setiap materi pembelajaran yang mendapat masing-masing tugas. Jika terdapat 15 materi pembelajaran, maka terdapat 15 pekerjaan rumah yang diberikan guru kepada siswa, dan hal inilah yang menjadi beban dan stressing bagi mereka.

Guru ataupun dosen tentu harus bijaksana memberikan keputusan, tidak memberi beban berlebihan kepada peserta didik terkait pekerjaan rumah, keberhasilan tenaga pengajar dalam pembelajaran adalah tingkat pemahaman murid yang mengerti dan paham materi pembelajaran, bukan beban pekerjaan rumah secara berlebihan yang 
CIVICS EDUCATION AND SOCIAL SCIENSE JOURNAL(CESSJ)

Volume 2 Nomor 2 Edisi Bulan Desember 2020

harus diselesaikan peserta didik. Pembelajaran virtual harus dirancang, bagaimana seluruh peserta didik mengerti dan paham terkait materi pembelajaran.Pada kesimpulan, tingkat pemahaman murid terhadap materi pembelajaran harus menjadi fokus utama guru dan dosen dalam pelaksanaan pembelajaran virtual.

\section{SIMPULAN}

Pandemic Covid-19 mengharuskan guru, dosen dan para peserta didik untuk melaksanakan pembelajaran virtual yang bertujuan memutus penularan virus pada tingkat lebih tinggi. Tantangan dan kendala dihadapi dalam pembelajaran virtual, masing-masing guru, dosen dan para peserta didik tentu memiliki pengalaman berbeda dalam melaksanakan pembelajaran virtual, namun terdapat pola permasalahan yang sama, untuk selanjutnya menemukan solusi tersebut.

Solusi permasalahan pembelajaran virtual terdiri dari beberapa unsur, yaitu (1) kesiapan guru dan dosen mengoperasikan perangkat teknologi informasi, (2) Jaringan internet yang stabil pada beberapa wilayah di Indonesia (3) Insentif biaya bagi peserta didik untuk membeli kuota internet (4) metode pembelajaran guru atau dosen yang inovatif (5) tidak memberi beban pekerjaan rumah secara berlebihan kepada siswa.

\section{REFERENSI}

Brahma, I.A., (2020). Penggunaan Zoom Sebagai Pembelajaran Berbasis Online Dalam Mata Kuliah Sosiologi dan Antropologi Pada Mahasiswa PPKN, Aksara-Jurnal Ilmu Pendidikan Nonformal, vol. 6, no. 2, pp. 97-102.

Creswell, John W. (2013). Research Design Qualitative, Quantitative, and Mixed Methods Approaches.third Edition, Terjemah, Achmad Fawaid, Research Design Pendekatan Kualitatif, Kuantitatif, dan Mixed. Yogyakarta: Pustaka Pelajar.

Huda, Y., Faiza, D. (2019).Desain sistem pembelajaran jarak jauh berbasis smart classroom menggunakan layanan live video webcasting, Jurnal Teknologi Informasi dan Pendidikan, vol. 12, no. 1, pp. 31-37.

Ibrahim, N., and Ishartiwi. (2017). Pengembangan Media Pembelajaran Mobile Learning BerbasisAndroid Mata Pelajaran IPA Untuk Siswa SMP, Jurnal RefleksiEdukatika, vol. 8, no. 1, pp. 81-88.

Maharani, N., Kartini, K.S. (2019). Penggunaan google classroom sebagai pengembangan kelas virtual dalam keterampilan pemecahan masalah topik kinematika pada mahasiswa jurusan sistem komputer, PENDIPA: Journal of Science Education, vol. 3, no. 3, pp. 167-173. 
Nirfayanti., Nurbaeti. (2019). Pengaruh media pembelajaran google classroom dalam pembelajaran analisis real terhadap motivasi belajar mahasiswa, Jurnal Penelitian Matematika dan Pendidikan Matematika, vol. 2, no. 1, pp. 50-59.

Nurfalah, E. (2019). Optimalisasi e-learning berbasis virtual class dengan google classroom sebagai media pembelajaran fisika, Physics Education Research Journal, vol. 1, no. 1, pp. 46-55.

Rikizaputra., Sulastri, H. (2020). Pengaruh e-learning dengan google classroom terhadap hasil dan motivasi belajar biologi siswa, Lectura: Jurnal Pendidikan, vol. 11, no. 1, pp. 106-118.

Setyadi, D. (2017).Pengembangan mobile learning berbasis android sebagai sarana berlatih mengerjakan soal matematika, Jurnal Satya Widya, vol. 33, no. 2, pp. 87-92.

Susanto, H., Widiartin, T., Pratama, F.H. (2016). Aplikasi Pembelajaran Berbasis Android (E-Learning) Di MA Daruttaqwa Gresik, Information Technology Journal, vol. 2, no. 2, pp. 82-88.

Tafqihan, Z. (2011). Karakteristik Dan Pemilihan Media Pembelajaran Dalam ELearning, Jurnal Cendekia, vol. 9, no. 2, pp. 142-154.

Yanto, B., Setiawan, A., Husni, R. (2020). PKM Blended Learning dengan Google Classroom for Education bagi Guru SMA Sederajat di Kecamatan Tambusai Provinsi Riau, Qalamuna-Jurnal Pendidikan, Sosial, dan Agama, vol. 12, no. 1, pp. 15-24.

Zhafira, N.H., Ertika, Y., Chairiyaton. (2020). Persepsi mahasiswa terhadap perkuliahan daring sebagai sarana pembelajaran selama masa karantina covid-19, Jurnal Bisnis dan kajian Strategi Manajemen, vol. 4, no. 1, pp. 37-45. 